\title{
The Implications of Post-Transition for Art and Aesthetics
}

Abstract: In contemporary anthropology, art history and aesthetics, the concept of transition is meant to signify and explain the hybrid set of changes that occurred in society, culture and the arts following the fall of the Berlin Wall or, more accurately, after the end of the Cold War. The assumption is that there is a relation of contingency between art, culture and society, which may produce the impression of a relation of causality.

Keywords: art, aesthetics, transition, post-transition

UDK 7:111.852:316.323.6

\section{Potranzicijske implikacije za umetnost in estetiko}

Izvleček: V sodobni antropologiji, umetnostni zgodovini in estetiki naj bi koncept tranzicije označeval in pojasnjeval hibridni komplet sprememb, ki so se po padcu Berlinskega zidu ali, natančneje, po koncu hladne vojne zgodile v družbi, kulturi in umetnosti. Tukaj je predstavljena predpostavka, da obstaja odnos kontingence med umetnostjo, kulturo in družbo, ki lahko naredi vtis, da gre za odnos vzročnosti.

Ključne beside: umetnost, estetika, tranzicija, potranzicija

$$
\text { * * * * }
$$

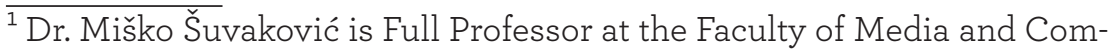
munication, Belgrade, Serbia. Email: miodragsuvakovic@gmail.com.
} 
state of emergency

is

my normal mode

of

life

In contemporary anthropology, art history and aesthetics, the concept of transition is meant to signify and explain the hybrid set of changes that occurred in society, culture and the arts following the fall of the Berlin Wall or, more accurately, after the end of the Cold War. The assumption is that there is a relation of contingency between art, culture and society, which may produce the impression of a relation of causality.

Today, "transition” typically signifies moving away - either gradual, as in a crisis, or accelerated, as in a break - from Cold War, realsocialist, state-socialist and self-managed society, culture and art toward a reconstructed and, in certain cases, even restored bourgeois society, that is, toward introducing and implementing liberal, typically also national, capitalism. ${ }^{2}$

Beyond the context of Europe, the concept of "transition" serves to signify political changes from the colonial to the postcolonial condition of Third World societies and states. ${ }^{3}$ The postcolonial condition is viewed as a process of transition that enabled ethnic/national and state-building liberation from colonisation and resulted in the emergence of independent or partly independent Third World states, whether liberal or real-socialist. With the conclusion of the Cold War, the world entered yet another transition leading from realsocialist postcolonial societies toward liberal or post-secular soci-

\footnotetext{
Todorova, 2010; Piotrowski, 2012.

${ }^{3}$ Godiwala, 2007.
} 
eties/states, whereby both liberal and post-secular societies have faced re-colonisation by multinational corporations and ethnic, national, or religious antagonisms of decolonisation. By itself, the concept of "decolonisation" contains another meaning as well: the critical-theoretical subversion of the postcolonial as a postmodernrecolonising notion, in other words, confronting the economic, political and cultural limits of contemporary global biopolitics and necropolitics ${ }^{4}$ applied to the transitional Third World.

One must carefully identify and differentiate between the concepts of "reconstructed" and "restored", because the differences between them are almost unnoticeable. To reconstruct means to construct something anew, something that had been constructed before and was then destroyed; furthermore, reconstruction proceeds with an insecure and uncertain vision of the future. Reconstruction is defined by a desire for a new future that might exceed that which is re-constructed. By contrast, restoration denotes the renewal of something that had "organically grown" and was then destroyed. When something is restored, it is renewed and consolidated with a vision of an imaginary past, which is meant to be affirmed at every subsequent moment in the future.

In more detail: In everyday speech, the word "transition" denotes the transformation of socialist or communist societies into liberal, capitalist societies with parliamentary democracy, i.e. into democratic societies. In terms of government, "transition" is the transformation of people's democracies led by the one-party "avant-garde of the working class" to multi-party parliamentary democracies with separate - legislative, executive and judiciary - branches of power. In terms of economy, transition denotes the transformation of economies based on social or state ownership into economies based

\footnotetext{
${ }^{4}$ Mbembe, 2003 .
} 
on or dominated by private ownership. In geopolitical terms, "transition" signifies - paradoxically - the emergence of national states (on the localising level) participating in the global economy and information system (the globalising level). In symbolic terms, transition begins by introducing a multi-party political system and ends by implementing a total or near-total privatisation of state and social property. In terms of the aesthetic, transition is the "pluralisation of sensory regimes" ranging from media to spectacle production in mass and global, market- and software-determined culture. In terms of art, transition is a retreat from "artistic practices that are characteristic of closed societies" into a global artistic practice with sustainable local references. On its way from real socialism to contemporary global capitalism, transitional art switches between various orientations, with specific narratives and relations with the public organisation of contemporary forms of life:

- artistic practices featuring the deconstruction of socialist-realist, socialist-modernist and socialist-postmodernist artistic practices; ${ }^{5}$

- art of the politics of difference, ${ }^{6}$ characteristic of postmodernity for instance, feminist, gender and queer art, postcolonial art, racial art, artistic practices in the liminal zones of popular and high culture, etc.;

- technocratisation of contemporary artistic practices by linking up with "creative industries", "corporate art", "therapeutic artistic practices", 7 etc.;

- critical, subversive and activist artistic practices, ${ }^{8}$ as a reaction to "post-politics", i.e. to the liberal-postmodern transition from pol-

\footnotetext{
$\overline{5}$ Erjavec, 2003; Irwin, 2006.

${ }^{6}$ Foster, 1999, 140-141.

${ }^{7}$ Chiu, Genocchio, 2010.

${ }^{8}$ Klanten et al., 2011.
} 
itics as a social practice to managerial policy-making in culture and society;

- artistic practices at the time of the "return of the political", ${ }^{9}$ i.e. in the conditions of the global economic crisis, the domination of political, media and cultural pluralism and establishment of local autocracies.

To be sure, one may also depoliticise the concept of transition and thereby point to "immanent artistic transitions", for instance, from functional bourgeois or real-socialist art to non-functional, i.e. autonomous art. ${ }^{10}$ One may also apply the concept of transition to changes in art in relation to the type of artistic or cultural ${ }^{11}$ creative/productive work - from manual via mechanical to electro-mechanical, analogue and digital work, i.e. mediation through media in relation to social or cultural formats, etc.

Perhaps one could argue that transition was anticipated by the concept of ending the "struggle for workers' rights"12 - following the collapse of the miners' strike in Great Britain - during the stabilisation of neoliberalism under Margaret Thatcher as prime minister. One should not forget Thatcher's famous slogan: "There is no alternative!" One could interpret her assertion in two ways: either there is no political or economic alternative to the contemporary rise of neoliberalism or every future alternative practice will be appropriated by the dominant neoliberal order and thereby transformed into a social market-economic artefact.

Historically, one could argue that transition began with the 1980s "singing" or "coloured revolutions" in the Soviet Bloc, which

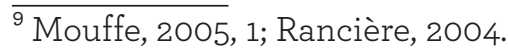

${ }^{10}$ Šuvaković, 2009.

${ }^{11}$ Lovink, 2002.

${ }^{12}$ Hall, 1988.
} 
culminated with the fall of the Berlin Wall, coming to an end at different moments of implementing privatisation from the early $1990 \mathrm{~s}$ to the mid 2010s. As a process of transition, post-socialism began in post-communist Europe with numerous reform and revolutionary events, which led to the end of the Cold War. The very beginning of that process was the crisis of the Polish state, provoked by the activities of the anticommunist and pro-national-democratic workers' movement Solidarity (Solidarnośc), founded at Gdansk Shipyard on 31 August 1980. The collaboration between the unions and the Catholic Church triggered the Polish national revolution, which ended with the Solidarity's victory in the parliamentary elections of 1990. Soviet leader Mikhail Gorbachev's project called "Perestroika" (Перестройка) marked the beginning of democratic reforms, which led to the transition from socialist to capitalist society and the end of Soviet hegemony in Eastern Europe. Gorbachev's cabinet adopted the so-called Sinatra Doctrine, ${ }^{13}$ whereby the Soviet Union stopped meddling in its allies' internal affairs. This doctrine opened the way for the collapse of communism in a number of Warsaw Pact member states and for the revolutions of 1989. The Baltic States, which had been integrated into the USSR immediately after the Second World War, saw the beginning of non-violent revolutionary movements called "the singing revolution" between 1987 and 1991. The first mass manifestations of national feelings occurred at the Tartu Pop Music Festival on 14 May 1988. The term "singing revolution" was then introduced by Estonian activist and artist Heinz Valk between 10 and 11 June 1988. He gave that name to the nightly demonstrations with singing organised at the Tallinn Song Festival Grounds. These were mass demonstrations involving around 300,000 Estonians, who gathered every night to sing na-

$\overline{{ }^{13} \text { Kushlis, } 2009}$. 
tional songs and anthems that were forbidden during the Soviet era. Demands for independence were openly made at a music festival held in Tallinn on 11 September 1988. The so-called "Baltic Way" or "Baltic Chain" was a non-violent political event involving around two million people forming a human chain by holding hands across Estonia, Latvia and Lithuania on 23 August 1989. The chain was around 400 miles long. It marked the $50^{\text {th }}$ anniversary of the Molotov-Ribbentrop Pact signed in 1939 by the USSR and the Third Reich, when the Baltic States fell under Soviet control. Estonia's declaration of sovereignty was announced at a festival held on 16 November that year. When the Soviet army attempted to put an end to the independence movement, which had been running for four years by that time, Estonia announced the restoration of its independence. Following the announcement of Lithuania's independence restoration act on 11 and 13 January 1991, the Soviet army intervened, killing 14 civilians and arresting over a thousand people. The action of erecting "Barricades" was a political action that took place between 13 and 27 January 1991, as an act meant to stop a potential Soviet intervention. Czechoslovakia's pro-Soviet regime was toppled in the "Velvet Revolution", which saw revolutionary turmoil and protests between 16 November and 29 December 1989. The Romanian armed uprising, turning into a violent revolution, occurred between 16 and 22 December 1989. China witnessed large and violently suppressed protests between 15 April and 4 June 1989. Tiananmen, Beijing's central square, was occupied by students demanding the democratisation of China's society. Etc.

One should also distinguish between the terms "transition" and "revolution", 14 since the former involves a pragmatic and rational implementation of controlled and gradual changes that have the char-

$\overline{{ }^{14} \text { Egbert, } 1970 .}$ 
acter of a consensual harmonisation of two distinct systems or material practices according to established and mediated external criteria.

Whereas revolution denotes a sudden break producing radical, which means essential and complete, changes of a given state of affairs, transition signifies a gradual approximation of one system or practice to another system or practice. The initial system or practice is thereby abandoned and transformed into another system or practice - integrated into a differently ordered set of relations between that which is on the one hand and local and global public opinion on the other. By contrast, revolution refers to the destruction of the structural order of a system or practice. According to Antonio Negri, however, revolution is a creative transformation that emerges from resistance to the "dark and terrorist being of the state". The factors of revolution - revolt, resistance and constitutive power - are presented as a temporal event, an event in and with time. As a temporal event, revolution shows that "revolt", "resistance" and "constitution" are related to time. Rather than a "space", time is a "phenomenon" connected to revolution: space is something one occupies, whereas time happens - just as a revolution happens. A revolution is at once an event of insurrection and resistance happening at a certain point in time that is necessarily "contemporary" - a literal performance of that NOW. Revolution constitutes a demonstration of the character of that contemporaneity - how contemporaneity acquires its meaning. Negri's phrase "time for revolution" 15 may be understood not only in terms of a point in time when a revolution should occur, but also in terms of constituting revolutionary time.

Transition also effects a relocation and reorganisation - reintegration - of one system and practice into another. In public opinion,

$\overline{{ }^{15} \text { Negri, } 2003 .}$ 
transition is presented as "gradual and justified progress" and not in terms of explosive destruction giving rise to a new order. Transition is therefore an ideologically mediated order of events that hide their real intentions. Due to the fetishisation of "progress", transition cannot be identified with restoration. Then, however, the following question arises: does the concept of progress also involve the concept or effects of emancipation as an important indicator? A revolution occurs when there is a dominant feeling that there is no time left and that everything must be settled now, whatever the price. By contrast, restoration occurs when in public opinion there emerges or is realised the feeling that we have gone too far in our pursuit of the new and now find ourselves in unfamiliar territory, that we must go back and seek safety in a domain of living and acting bound by tradition. Transition emerges as a situation where we are in control of time and are aware that things are solved gradually - slowly - by proceeding by the smallest steps that will, by means of accumulating life, economy and politics, eventually yield results. In any case, it is always an ideology that names and represents "change" in a pragmatically instructive way!

However, the transition from real and self-managed socialism to bourgeois, liberal society based on private property brought an established order to an end and enabled the introduction of a new order and reintegration in such a way that both orders found themselves in the situation of the "end of an order" - real-socialist and liberal society alike. This concerns the tactics of "echo" (in romanticist terms) or feedback (in pragmatic terms). In other words, the transition involved not only the "political East", but also the "political West". The end of an order appeared as an essential and total change - where total means global, while essential means a wholesale change of system and practices from one set of forms of life to an entirely different set. In the wake of the socialist and liberal order 
there emerged the hybridised order of global and mass economicrepresentative populism. Which means that, paradoxically, the mechanisms of transition appear as instruments that simulate revolutionary expectations and effects in a global sense.

In this context, post-transitional society denotes a "normalised" or "harmonised" society that has completed its transition from "socialism" to "capitalism", which means the establishment of

- a parliamentary democratic order,

- the domination of private ownership over state and social ownership,

- the implementation of globalisation in terms of market economy and media and communication.

Post-transition, hypothetically speaking, is not a stage of change, but of reaching stabilisation by societies seeking to join the global order; accordingly, for instance, Europe should no longer be divided into Western and Eastern Europe in political-economic terms, which also means cultural, i.e. artistic terms. One then arrives at an entirely harmonised or regulated world image that brings together the local and global public, at least at the level of an individual consumer, that is, a distant accomplice or, frequently, subcontractor, in a complex process of production, exchange and consumption.

The preceding opening paragraphs have defined/redefined the concepts of "transition" and "post-transition" in the usual sense of the contemporary usage of those concepts. For instance, Cuba today stands at the beginning of its transition, Serbia is at the end, while, for example, Slovenia, Poland, Hungary and Russia are in post-transitional stages. Some transitional societies in post-transition adopt the conditions and circumstances of the global state of affairs, i.e. the global view of the world as a public view of the world. We must now return to re-examining the concept and phenomenon 
of "transition". One may indicate the concept and phenomenon of transition by means of four theoretical indicators and a fifth metaindicator:

\section{phenomenology of TRANSITION}

\begin{tabular}{|c|c|c|c|}
\hline change & flow & transformation & transfer/transferring \\
\hline \multicolumn{4}{|c|}{ effect of revolution } \\
(qua accumulation of changes, flow, transformation and transfer/transferring toward a radical break) \\
\hline
\end{tabular}

"Change" signifies a set of social activities whereby a condition or stage of society undergoes a radical, sometimes even revolutionary change and comes to occupy a situation of redefining the local and global world image, which also includes the relations between local and global public and private forms of life. Change is redefined as a social process - a sort of subversive practice with consequences.

"Flow" signifies the uncertainty and irresolubility of permanent change in the course of our lives. No stable situation can be indicated. We cannot say that we have come from Condition A to Condition $B$ and that the flow, i.e. transition, is complete. The flow signifies the permanence of changes, transformations and transfers. From a pre-transitional condition or situation via a transitional one, we have come to a post-transitional condition or situation that is now a new situation, for instance, marked by the global economic crisis $^{16}$ and thereby initiated as a new flow of changes. At the same time, having attained the ideal or non-ideal paradigms of parliamentary democracy, we are facing a crisis of parliamentary democracy in the West itself and the transformation of the platforms of

\footnotetext{
${ }^{16}$ Lazzarato, 2009 .
} 
global neoliberalism ${ }^{17}$ into those of expansive populism, etc. The flow does not stop.

"Transformation" typically signifies a gradual event whereby one form of life becomes another form of life, that is, an event whereby one world image becomes a different world image. At the same time, there is an analogy between becoming and organic growth, that is, the growing up of a living being. The transformation of society is conceived as an allegorical image of the transformation of living organisms.

Transition is a sort of "transfer" of a situation from one context into another context. A transfer is initiated by an impulse that causes the transfer of a situation. Transferring causes changes not only in the situation that is being transferred, but also in the context from or into which it is being transferred - in addition, the aim is to show that there also occurs a counter-change in the "impulse" that initiated the transfer by the very event of the transfer. One therefore speaks of transfer and counter-transfer. A transfer is the relocation of an X from one context into another. A counter-transfer is the counter-impact of relocating an X from one context into another that has consequences on the initiator, i.e. the impulse that initiated or caused the transfer. In other words, a form of life or world image in "transfer" is an event with double consequences, which occur in systems with feedback loops. By analogy with psychoanalytic thought, ${ }^{18}$ transfer initiates the patient's unconscious through the activity of the analyst, and the patient's unconscious initiates the analyst's unconscious as an effect-reaction. In other words, initiating transitional processes in the East by the West has the counter-effect of initiating transitional processes in the West by the East.

\footnotetext{
${ }^{17}$ Harvey, 2006.

${ }^{18}$ Lacan, 1981.
} 
In relation to social flows, one may say that the accumulation of changes, the flow, transformation and transfer/transferring toward a radical break appears as an "effect of revolution": a complete and essential end of an order and modality of its existence with counter-impacts on the social, political, economic and cultural potentials of the initiator/ideologue and surveillance of transition. A form of life is depleted and discarded. Its place is taken over by other forms of life emerging in the process of transition. In ideological-political terms, transition appears not as a revolution, but as its opposite; by virtue of the fundamental global change it effects, it has the phenomenological - phenomenal - character of a revolution.

Therefore, my claim in this discussion is that the "transfer", i.e. moving from Cold War, real-socialist, state-socialist and self-managed society, culture and art toward civil society, that is, toward introducing and implementing liberal, typically also national, capitalism, takes place not only in terms of the contents transferred (real-socialist, state-socialist and self-managed society, culture and art), but also in terms of making a counter-effect on the dominant world of the liberal West, which initiated these processes. The transition of Eastern Europe caused a counter-transfer in the society, culture and art of the original initiator of the "transfer", which was Western liberal capitalism. The global economic crisis is an indicator of that counter-transfer and its "painful" realisation.

From that first claim follows the second: that the transition of the political East to the economic-political West is not complete, because the very goal of that transition - i.e. the West's liberal democratic order - has undergone transitional changes that violate the propositions of liberalism and democratic order. The conception of transition as a controlled and regulated transitory interval of transfer from one world image into another is thereby brought into ques- 
tion. The idea of "permanent transition"19 emerges as an attractive model that one could trace, though not without irony, from the dialectics of Heraclitus to that of Marx, or connect to Leon Trotsky's idea of "permanent revolution". ${ }^{20}$ It may be traced all the way to neoliberal economy with its base in a constant inflation of surplus value and uncontrolled changes in the distribution of social income both locally and globally.

Having posited the indicators of operative concepts and having indicated a "hypothetical metaphysics of transfer and countertransfer", one may argue that contemporary aesthetics as a theoretical practice and contemporary art as a practical theory participate in the fictionalisation or de-fictionalisation of the "transitional human condition".

That is meant to show that contemporary transition is a totalising process with all its transfers and counter-transfers, encompassing humankind in relation to its geographical locations, global/networked relations and phase-dislocated historical identifications in contemporaneity. Thus we see that transition, as permanent processing, resonates with politics, economics, social dynamic structures, ethics, art, distributions of sensuality. Thus all of human reality is inscribed into a broad constellation of signifiers, i.e. a map of dynamic vectors and vector consequences (economic effects and human affects) whereby transition unfolds in the direction of transfers and counter-transfers.

\footnotetext{
${ }^{19}$ Enwezor, 2008.

20 Trotsky, 2010.
} 


\section{Bibliography}

CHIU, M., GENOCCHIO, B. (2010): "Corporate Culture”, in: Contemporary Asian Art, Thames and Hudson, London, 176-180.

EGBERT, D. D. (1970): Social Radicalism and the Arts - Western Europe: A Cultural History from the French Revolution to 1968, Alfred A. Knopf, New York.

ENWEZOR, O. (2008): "The Postcolonial Constellation: Contemporary Art in a State of Permanent Transition”, in: Smith, T., Enwezor, O., Condee, N., eds., Antinomies of Art and Culture: Modernity, Postmodernity, Contemporaneity, Duke University Press, Durham, NC, 207-234. ERJAVEC, A. (2003): "Introduction", in: Postmodernism and the Postsocialist Condition: Politicised Art under Late Socialism, California University Press, Berkeley, 1-4.

FOSTER, H. (1999): "For a Concept of the Political in Contemporary Art”, in: Recodings: Art, Spectacle, Cultural Politics, The New Press, New York, 139-156.

GODIWALA, D. (2007): "Postcolonial Desire: Mimicry, Hegemony, Hybridity”, in: Kuortti, J., Nyman, J., eds., Reconstructing Hybridity: Post-Colonial Studies in Transition, Rodopi, Amsterdam, 59-79.

HALL, S. (1988): The Hard Road to Renewal: Thatcherism and the Crisis of the Left, Verso, London.

HARVEY, D. (2006): A Brief History of Neoliberalism, Oxford University Press, Oxford.

IRWIN, eds. (2006): East Art Map: Contemporary Art and Eastern Europe, Afterall Books, London.

KLANTEN, R. et al., eds. (2011): Art \& Agenda: Political Art and Activism, Gestalten, Berlin.

KUSHLIS, P. H. (2009): "The Soviets, The Sinatra Doctrine and the Beginning of the Cold War's End”, http://whirledview.typepad.com/ whirledview/2009/11/the-soviets-the-sinatra-doctrine-and-the-beginning-of-the-cold-wars-end.html. 
LACAN, J. (1981): The Four Fundamental Concepts of Psycho-Analysis, W. W. Norton \& Co. Inc., New York.

LAZZARATO, M. (2009): "On the Crisis: Finance (or Property Rights) versus Social Rights”, in: Szewczyk, M., ed., Meaning Liam Gillick, The MIT Press, Cambridge, MA, 147-156.

LOVINK, G., ed. (2002): Uncanny Networks: Dialogues with the Virtual Intelligentsia, The MIT Press, Cambridge, MA.

MBEMBE, A. (2003): “Necropolitics”, Public Culture, 15(1), 11-40.

MOUFFE, C. (2005): The Return of the Political, Verso, London.

NEGRI, A. (2003): “The Constitution of Time”, in: Time for Revolution, Continuum, New York, 19-135.

PIOTROWSKI, P. (2012): “Agoraphilia after Communism”, in: Art and Democracy in Post-Communist Europe, Reaktion Books, London, 7-14. RANCIÈRE, J. (2004): "The Distribution of the Sensible: Politics and Aesthetics", in: The Politics of Aesthetics: The Distribution of the Sensible, Continuum, London, 12-19.

ŠUVAKOVIĆ, M. (2009): "Around Althusserian-Lacanian Critique of Autonomy of Art: Class and the Unconscious", in: Tratnik, P., ed., Art: Resistance, Subversion, Madness, Monitor ZSA, 31/32, 9(1-2), 31-35. TODOROVA, M. (2010): “The Process of Remembering Communism", in: Remembering Communism: Genres of Representation, Social Science Research Council, New York, 9-34.

TROTSKY, L. (2010): "What Did the Theory of the Permanent Revolution Look Like in Practice?", in: The Permanent Revolution, and Results and Prospects, Red Letter Press, Seattle, 231-252. 